\title{
Stress Among Selected Library Practitioners in Nigerian: A Diagnosis and prescription.
}

\section{BY}

\author{
Chuma Opara NNADOZIE, and Emmanuel Uwazie ANYANWU,
}

\begin{abstract}
Stress prevalence in the larger society also affects library practitioners. This makes stress studies amongst these information professionals both topical and challenging. The subsisting dearth of stress-based reports in the library professional literature available to the researchers provided further motivation for this investigation. The research setting is Imo State of Nigeria while the subjects of study consist of librarians and library officers drawn from different in the state libraries. Data were collected through a customized questionnaire designed to elicit information on signs, types, causes, consequences and remedies to stress among the respondents. Results show that the major signs of stress are tiredness, headache, forgetfulness and insomnia resulting from unfavorable situations and events at home and work place, in addition t, negative personal lifestyle. The major consequences of stress revealed in this study included: decline in productivity, quarrelsomeness, martial crises and in health complications. Adequate remuneration of library staff, positive lifestyle and other remedies proffered in this report, which were influenced by the findings, would assist in ameliorating the adverse consequences of stress amongst library personnel in the study location and elsewhere.
\end{abstract}

\section{Introduction}

Stress is one concept that evokes divergent opinions from endocrinologists, psychologists, medical doctors and sociologists, among other stress scholars. One of these definitions propounded by Gibson, Ivancevich and Donnel (1994) saw stress as "an adaptative response, mediated by individual differences and/or psychological processes resulting from environmental action, situation, or event that places excessive psychological and/or physical demands on a person." This somewhat complicated description was simplified by Okoye and Chikwe (2007) as "the wear and tear the human body undergoes as it tries to adjust to continually changing environment".

The impacts of stress on an individual are as many as they are diverse. However, despite its extensive pejorative usage, available literature does not support the position that stress has a completely negative connotation. For instance, eustress (meaning "good feeling") coined by Dr. Hans Selye (1976), the pioneering stress researcher, is both positive and necessary because it engenders self-motivation, stimulates handwork and increases inspiration to live a better life. This, however, does not delete or diminish the many disruptive and potentiallydangerous consequences of stress most of which are imperceptible. Cox (1978), categorizes the various adverse effects of stress into five broad groups, namely: subjective, behavioral, cognitive, physiological and organizational.

The foregoing implies that specific environmental conditions, whether tangible or otherwise, are potential sources of stress. The nature of a person's occupational or professional involvement is inversely proportional to the amount of exposure to stress. Besides, there is the issue of the unique individual characteristics of human beings. The bottom-line is that stress is an inevitable component of human existence and therefore cuts across various professions and strata in a society.

The various cadres of library practitioners, being integral members of stress-prone larger society, undoubtedly have their fair share of the pressures of life. It cannot be denied that a substantial amount of the stresses to which library personnel are exposed to emanate directly from events and issues at home and at the work places. Whereas the negative consequences of such job-associated stress have been acknowledged (Obi, 2003), available literature revealed that library scholars and researchers have not devoted much time to investigate the impact of stress on their members.

The non-availability of many published reports on stress among library workers is underscored by the increased involvement of these professionals in researches and publication in the area. Consequently, the analysis of the prevalence, types, causes and remedies to stress among library personnel formed the major thrust of this report. Imo State was chosen as the study-area on the premise that the respondents drawn from the large population of librarians and library officers, affiliated to different sub-groups of libraries within the study would yield data which may reflect the stress situation amongst library practitioners in other parts of Nigeria.

\section{Literature Review}

A survey by the Minneapolis-based North Western National Life (NWNL) Insurance Company showed that stress among the populace has been on the increase (NWNL, 1991.) Such incidences of stress result from the interaction of the individual with his environment (Numerof, 1983). These environmental factors that expose people to different degrees of pressure (stress) are prevalent at home and in workplaces. An evaluation of occupational stress by Holt (1982) revealed that age, sex, work, addition, 
self-esteem and community involvement are some of the individual differences that affect reaction to stress. However, stress at work and non-work activities are interdependent. Gibson, Ivancevich and Donnel (1994:265) observe the interdependence "as a consequence of stressors experienced at work. The individual may come home irritable, short-tempered, fatigued and argue with spouse. The resulting marital conflict may be a source of subsequent stress that in turn negatively affects job performance".

Warren and Towl (1995) identified several negative consequences of workplace stresses which include absenteeism, low morale and low productivity. In an earlier study, Stonier (1992) observed that the early physiological symptoms of stress in workplace include: elevated blood pressure, increased heart rate, sweating, hot flashes, headaches and gastro-intestinal disorder. It has been stated in Time Digest (2002) that, stress does not only affect the emotional side but also the health. This explains the position of KiecoltGlaser and Glaser (1987) that major and minor stressors may lead to change in immune system functioning and the associated heightened frequency of distress. This makes stress one of the serious phenomena affecting the achievement of organizational effectiveness (Obi, 2002). Frogatt and Stamp (1991) added that "working conditions that are stressful create a climate of frustration and tension, which is often disregarded by people in positions of authority".

Another study by a team of stress-researchers revealed that withdrawal and non-productive behaviours such as burnout, alcoholism and drug abuse are the most costly effects of stress especially from the management perspective (Gibson, et al, 1994.) This is because, directly or indirectly, stress increases the operational cost of an organization. Besides the reduction in staff productivity, Karasek and Theorell (1990) reported that employers in Western countries have been bearing the burden of stress-related compensation claims which have grown dramatically in the past decades.

Scholars have recommended strategies for curtailment of the negative aspects of stress. Maturi (1992) suggests that workplace stress could be reduced if employees are recognized and rewarded fairly for their contributions, in addition to development of stress test scale to highlight possible trouble areas. Gibson and Associates (1994) recommend that improving channels of communication, creating a positive corporate culture, helping employees with health problems and determining what employees consider to be job stressors, are steps in the right direction. Lefkoe (1992) adds that employers should provide medical and counseling services for their employees as a deliberate strategy to reduce the adverse effects of stress at the workplaces. In a treatise on staff management in library and information work, Jordan and Norah (1995) submitted that stress among library workers could be alleviated through job-redesign and flexible work schedule. Adair and Stonier (1990) added financial reward, staff training and proportion as possible sources of relief from stress.

\section{Objective of the Study}

It has been established that stress is a corollary of human existence (Selye, 1976; Lauerman, 1992, etc). This study is an attempt to generated credible information on the causes of stress among library personnel, types of stress prevalent in the study area and the relief for such stressors. It would kindle the interests of librarians and other information professionals to keep stress-studies among practitioners in the front-burner, so as to make positive contributions to the growing corpus of literature in the area.

\section{Methodology}

This is a descriptive research in which data were generated with the aid of a self-developed questionnaire captioned "Questionnaire on Stress Amongst Library Personnel”. Repeated validation by different senior librarians left the surveyors with a concise research instrument containing specific questions on signs, causes, types, negative effects and remedies to stress among respondents. Sixty (60) copies of the instrument were administered by the researcher to librarians and library officers during the $3^{\text {rd }}$ Quarterly General Meeting of Imo State Chapter of the Nigeria Library Association (N.L.A.) in 2007. The respondents were allowed to choose freely from the options accompanying each query, if need be. Fifty-four (54) copies of the said questionnaire (i.e. $90 \%$ ) were completed and returned in usable condition. The findings were collated, analyzed and presented using frequency tables and simple percentage counts.

\section{Research Findings and Discussion}

The analysis of the gender distribution of the respondents showed that out of 54 of them, $31(57.4 \%)$ were females while $23(42.6 \%)$ were males. This finding implies that there are more female librarians working in Imo State of Nigeria. This unwillingly buttresses earlier findings about the gender distribution of librarians in other parts of the country (Agboola and Oduwole, 2000; Oduwole and Ikhizama,2007, etc.) Of the respondents, 44(81.5\%) were married. They fell within the age brackets, of 20 - 35 years (19/35.2\%), 36 - 50 years (32/59.3\%), 51 years and above $(3 / 5.6 \%)$.

On their academic qualifications and proficiency in Library \& Information Science 5.6\% have Ph.D (Library Science), $31.5 \%$ have Master of Library 
Science, $20.4 \%$ have Bachelors of Library Science and $42.6 \%$ have Higher National Diploma. Thus while the holders of the Ph.D certificates are few, those with Diplomats in Library Science are the largest group of library personnel in the study area. This distribution could be understood from the perspective that $\mathrm{Ph} . \mathrm{D}$ programme is both demanding and stressful and could scare many people away. The existence of the pioneer training institution for Diploma in librarianship programme in Imo State might have accounted for the large number of this cadre of library staff in the state. A majority (59.3\%) of the respondents were in the various academic libraries in the state while the least of them (2/3.7\%) were drawn from school libraries. The major signs of stressed experienced by the respondents are shown in Table I:

Table 1: Sings of Stress Experienced by Respondents: ( $\mathrm{N}=54)$.

\begin{tabular}{|l|c|c|}
\hline Type of Signs & Frequency & Percentage \\
\hline Tiredness & 46 & $85.2 \%$ \\
\hline Headache & 31 & $57.4 \%$ \\
\hline Forgetfulness & 16 & $29.6 \%$ \\
\hline Sleeplessness & 14 & $25.9 \%$ \\
\hline Aching muscles & 14 & $25.9 \%$ \\
\hline Irritability & 10 & $18.5 \%$ \\
\hline Chest pain & 6 & $11.1 \%$ \\
\hline Sweaty palms & 5 & $9.3 \%$ \\
\hline Indigestion & 1 & $1.9 \%$ \\
\hline
\end{tabular}

Note: Multiple answers inclusive

Some of the unpleasant signs of stress experienced by participants in the present study are presented in Table 1 above. It is clear that tiredness (85.2\%), headaches $(57.4 \%)$ and forgetfulness $(29.6 \%)$ are the major signs with chest pain $(11.1 \%)$, sweaty palms $(9.5 \%)$ and indigestion $(1.9 \%)$ as the minor. Although no profession is stress-free (Numerof, 1983), the result presented in Table 1 should serve as a clarion call on the stakeholders in librarianship in Nigeria and elsewhere to map out strategies for the alleviation of stress among librarians and other information practitioners. This is supported by other researchers such as Frogatt and Stamp 1991; Stonier 1992; Kiecott-Glaser and Glazer 1987; Warren and Towl, 1995 and Obi, 2002.

The factors which predispose individuals to stress usually result from what is seen, heard, touched, felt, smelt, eaten, said or done. Stressors are present at home, in the workplaces, recreational spots and sundry places where the individual might be for one reason or the other. Hence the conception that stress is seen as an inevitable part of human existence (Selye, 1976). Stressors are so pervasive that even substances taken out of proportion could expose the individual to stress (Gibson, et al, 1994). The applicability of this position on the respondents was proved by the respondents who showed different degrees of stress upon the ingestion of certain substances and foods. This is shown in Table 2 below:

Table 2: Stress-inducing Substances. :( $\mathrm{N}=54)$.

\begin{tabular}{|l|c|c|}
\hline Options & Frequency & Percentage \\
\hline $\begin{array}{c}\text { Caffeinated } \\
\text { ubstances }\end{array}$ & 23 & $45.5 \%$ \\
\hline Coffee & 18 & $33.3 \%$ \\
\hline Refined sugar & 17 & $31.5 \%$ \\
\hline Alcohol & 8 & $14.8 \%$ \\
\hline Excess salt & 3 & $5.6 \%$ \\
\hline Tobacco & - & - \\
\hline Illicit drugs & - & - \\
\hline None of the above & 13 & $24.7 \%$ \\
\hline
\end{tabular}

Note: Multiple answers inclusive

People respond differently upon consumption of certain foods or edibles which are otherwise regarded as common and harmless. That explains the psychological concept of individual differences. Although Table 2 shows that caffeinated substances ranked as the major stressor to respondents, this does not diminish the fact that it does not happen to everybody. While some of the foods and substances in Table 2 are agreeable with some people, they resulted in restlessness, sleeplessness and other negative consequences for many respondents to this study. Hence the need for library practitioners to always consult see nutritionists on what they eat and also conduct relevant medical checks before ingesting anything to avoid discomfort at home and office. On tobacco and illicit drugs a sizable number of the respondents were found to be smokers of cigarette and other tobacco products. The fact that none saw tobacco products as stressors could be because of the society's disapproval of smoking and smokers. It could also be that they are yet to be unaware of the harmful effect of their lifestyle. Irrespective of the findings of this study, drinking of alcoholic beverages remains a popular pastime for many people, irrespective of professional affiliation or social standing. Cattano (1987) describes this inclination known generally as alcoholism as a disease characterized by repeated excessive drinking that interferes with an individual's health and work behaviour. The early stages of this indulgence are often difficult to detect since it is not always accompanied by deteriorating job performance or noticeable change in behaviour. However, the dipsomaniac tend to manifests various negative traits, including absenteeism, quarrelsomeness lack of concentration and low productivity over time.

On illicit drugs usage, there is a disturbing increase in the proportion of the population that take banned drugs like marijuana, cannabis, cocaine, heroin, etc (Moss, 1989; Baker, 1989). Giving insight into this problem and its connection to the present discuss, Gibson and Associates (1994:83) reported that: "One contributor to drug abuse is stress stemming from the 
job. Stimulants and hallucinogen (e.g. marijuana and cocaine), narcotics (e.g. heroin and Demerol), and sedative-hypnotics (e.g. barbiturates and Valium) are taken by employees across all job categories to relieve job boredom, excessive stress, and related work problems". Since these drug addicts and abusers cut across different professions, there is no doubt that librarians, especially the younger ones may be involved. Even though there could be users of banned drugs amongst the respondents, the illicit nature of their indulgence, societal disapproved and fear of exposure-cum-apprehension could account for their inability or failure to indicate their preferences. However, regardless of the pressure of work, librarians are advised to be good role-models to their clients by avoiding negative behaviours.

Table 3: Ranked Order of Major Emotional Stressors: $(\mathrm{N}=54)$.

\begin{tabular}{|l|c|c|}
\hline Emotional Stressors & Frequency & Percentage \\
\hline Anger & 25 & $46.3 \%$ \\
\hline Frustration & 21 & $38.9 \%$ \\
\hline Fear & 19 & $35.2 \%$ \\
\hline Intimidation & 17 & $31.5 \%$ \\
\hline Weakness & 14 & $25.9 \%$ \\
\hline None of the above & 11 & $20.5 \%$ \\
\hline Others & 16 & $29.6 \%$ \\
\hline
\end{tabular}

Note: Multiple answers inclusive

The psychological state of an individual exposes that person to certain degrees of stress. Bearing this in mind, the respondents were asked to indicate as any as possible the emotional conditions that predispose them to stress. The result, as presented in Table 3, reveals that the major psychological or emotional stressors are anger (46.3\%), frustration (38.9\%), fear $(35.2 \%)$, intimidation $(31.5 \%)$, and weakness $(25.9 \%)$. Personnel who experience the above stressors would definitely have difficulties achieving the required level of concentration for optimal performance on the jobs (Lauerman, 1992; Gibson, et al, 1994; Obi, 2003, etc). Since librarianship is a service-oriented profession, the practitioners should adopt strategies aimed at stress-minimization, increased productivity and enhanced public image. For instance, an angry or frustrated library staff may not have the state of mind required for the provision of satisfactory services to the clientele.

Table 4: Ranked Distribution of EnvironmentAssociated Stressor ( $=54)$.

\begin{tabular}{|l|c|c|}
\hline Options & Frequency & Percentage \\
\hline Noise & 31 & $57.4 \%$ \\
\hline Dirty surrounding & 26 & $48.1 \%$ \\
\hline Air pollution & 24 & $44.4 \%$ \\
\hline Extreme heat of cold & 19 & $35.2 \%$ \\
\hline Traffic congestion & 15 & $27.8 \%$ \\
\hline Others & 13 & $24.1 \%$ \\
\hline
\end{tabular}

Note: Multiple answers inclusive
Man is a social being whose existence is characterized by unending interaction with any environment in which he finds himself. While the benefits of this social intercourse are not in doubt, there should be no let-up in the effort to check any unpleasant aftermath. Thisis possible when those environmental stressors are identified. The five major environmental stressors identified by respondents are shown in Table 4 were: Noise $(57.4 \%)$, dirty surroundings $(48.1 \%)$, and air pollution $(44.4 \%)$. Others are extreme weather condition (35.2\%) and traffic congestion (27.8\%). Some of these factors are man-made while others are natural. They also have consequences which are capable of undermining the productivity, social interaction, emotional stability and professional competence of the effected. Although, the negative impacts of these environmental stressors are not restricted to library practitioners, it is nevertheless, timely to draw their attention to them. This will help in the design of strategies for the management, control and reduction of the manifold harmful effects of such inevitable stressors.

Table 5: Home-induced Stressors N = 54).

\begin{tabular}{|l|c|c|}
\hline Response & Frequency & Percentage \\
\hline Insufficient income & 32 & $59.3 \%$ \\
\hline Rising expenditure & 30 & $55.6 \%$ \\
\hline $\begin{array}{l}\text { Accommodation } \\
\text { roblem }\end{array}$ & 25 & $46.3 \%$ \\
\hline Family pressure & 21 & $38.9 \%$ \\
\hline Inadequate time & 18 & $33.3 \%$ \\
\hline
\end{tabular}

Note: Multiple answers inclusive

Stress also emanates from situations and incidences at home. The stressors arising from the state of things in the residences of respondents are analyzed and presented in Table 5: "Insufficient income" (59.3\%) and "rising expenditure" $(55.6 \%)$, which are the most prominent of this category of stressors, are somewhat interrelated. Library workers, most of who are inadequately remunerated, would have difficulties meeting important personal and family needs, in addition to other social commitments. This is a veritable source of stress, especially, in a period of inflationary trends and poor remuneration as witnessed in the country in recent times. Accommodation is bound to create problems for most respondents considering that only few (11 or 20.4\%) of them had personal residential buildings leaving the other $46.3 \%$ to make do with inadequate rented apartments. The rest of the major home-induced stressors are various demands from spouse, children and dependents (38.9\%) and inadequate time to provide personal, family and other needs $(33.3 \%)$. It is not difficult to appreciate the interrelatedness of the last two home-induced stressor. The study location, being a typical African setting, cannot be divorced from the extended family phenomenon. The respondent therefore have to contend with pressures 
from dependants who are not members of their nuclear families. Discharge of this culture-induced obligation takes time and resources both of which are insufficient, thereby exacerbating stress situation amongst respondents. These pressures (stressors) are by no means peculiar to library personnel. It might well be a pointer to the extent of stress prevalence in other professional groupings.

Table 6: Employment-Related Stressors $(\mathrm{N}=54)$.

\begin{tabular}{|l|c|c|}
\hline Options & Frequency & Percentage \\
\hline Insufficient salary & 41 & $75.9 \%$ \\
\hline Work overload & 33 & $61.1 \%$ \\
\hline $\begin{array}{l}\text { Inadequate working } \\
\text { bols }\end{array}$ & 32 & $59.2 \%$ \\
\hline $\begin{array}{l}\text { Transportation } \\
\text { ifficulties }\end{array}$ & 29 & $53.7 \%$ \\
\hline Bullying & 23 & $42.6 \%$ \\
\hline Career stagnation & 20 & $37.0 \%$ \\
\hline Retirement blues & 17 & $31.5 \%$ \\
\hline
\end{tabular}

Note: Multiple answers inclusive.

Not only do people spend a lot of time on workrelated activities, individuals find a substantial portion of their satisfaction and identity in their employment. Ironically, events and situation associated with work make people susceptible to various stressors (Holt, 1982). As shown in Table 6, library personnel are not exempted from employment-related stressor. It is understandable that as much as $75.9 \%$ of the respondents experienced stresses caused by insufficient remunerations considering that most librarians, employed largely by various tiers government are poorly paid when compared with medical doctors, bankers, engineers and political appointees. The issue of work overload could be a direct result of understaffing in most of the libraries in the area under study, as noticed in the course of this survey. Also, the fact that 'inadequate working tools' made the list of major stressors suggests that respondents are willing to work but for the shortage or absence of basic library facilities. Other employment-related stressors of library workers identified in this study were: transportation difficulties $(59.2 \%)$, bullying and/or hostility from bosses and colleagues $(42.6 \%)$, stunted career progression $(37.0 \%)$ and uncertainties of life after retirement (31.5\%). Stress arising from transportation difficulties could be understood against the backdrop that majority of the respondents reside far away from their places of work, have no personal means of mobility, travel on badly constructed roads and content with poorly-managed transportation system. There is no doubt that a staff who is always at the receiving end of unnecessary hostility from bosses and colleagues alike, would not be comfortable in that employment, because career progression or advancement could be affected. The stress resulting from retirement blues is largely a reflection of the present uncertainty in the management of pension and gratuity in the country.

Table 7: Negative Consequences of Stress $(\mathrm{N}=54)$.

\begin{tabular}{|l|c|c|}
\hline Options & Frequency & Percentage \\
\hline Reduced productivity & 36 & $66.7 \%$ \\
\hline Quarrelsomeness & 31 & $57.4 \%$ \\
\hline Marital crises & 21 & $38.9 \%$ \\
\hline Insomnia & 19 & $35.2 \%$ \\
\hline Health complications & 17 & $31.5 \%$ \\
\hline Others & 15 & $27.8 \%$ \\
\hline
\end{tabular}

Note: Multiple answers inclusive.

Professionals in various fields experience different types of stresses as a direct result of their occupational affiliation. These stressors, more often than not, result from an interplay of series of incongruous situations arising from both work and non-work activities. There is no doubt that stresses have incalculable negative consequences which are not limited to library workers. The major side-effects of stress amongst library practitioners are shown in Table 7. Definitely, individuals that contend with the diverse stresses identified in Tables 3, 4, 5 and 6 cannot have the concentration, enthusiasm and professional commitment required for optimal productivity. This is particularly true of the library personnel, most of who work in poorly furnished offices bereft of basic professional tools, in addition to, salaries that are grossly insufficient when juxtaposed with the jumbo earnings of professionals in other fields like politics, medicine, engineering, banking, oil and gas, telecommunications. The pressures arising from this situation can also predispose the affected worker to picking quarrels, at the slightest provocation, both at home and in the office. The inability to meet family obligations and commitments could be attributed to the meager remuneration which is the lot of most library practitioners in the country. The foregoing problems could easily lead to sleeplessness. These factors provide an insight into the emergence of reduced productivity (66.7\%), quarrelsomeness (57.4\%), martial crises $(38.9 \%)$ and insomnia $(35.2 \%)$ as the major consequences of stress amongst the library staff who participated in this survey. Some of the health complications $(31.5 \%)$ identified by the respondents include hypertension, diabetes, tiredness, constipation, bad sight and loss of appetite. 
Table 8: Remedies to Stress $(\mathrm{N}=54)$.

\begin{tabular}{|l|c|c|}
\hline Remedies & Frequency & Percentage \\
\hline Better remuneration & 45 & $83.3 \%$ \\
\hline $\begin{array}{l}\text { Provision of working } \\
\text { pols }\end{array}$ & 35 & $64.8 \%$ \\
\hline Tranquil home in & 33 & $61.1 \%$ \\
\hline $\begin{array}{l}\text { Improvement and } \\
\text { vorking condition }\end{array}$ & 31 & $61.1 \%$ \\
\hline $\begin{array}{l}\text { Counseling } \\
\text { hedical services and }\end{array}$ & 30 & $55.6 \%$ \\
\hline $\begin{array}{l}\text { Encouragement and } \\
\text { ppreciation }\end{array}$ & 27 & $50 \%$ \\
\hline $\begin{array}{l}\text { Exercise } \\
\text { elaxation }\end{array}$ & & \\
\hline
\end{tabular}

Note: Multiple answers inclusive.

Although stress is inevitable, several strategies could be adopted to either curtail its occurrences or manage the consequences. Notwithstanding that the remedies to stress analyzed in Table 8 were generated by library personnel; they are easily applicable to professionals in other fields. There is no doubt that a well-paid staff would have the required financial resources to meet personal, family, professional and sundry financial obligations. The provision of the needed but lacking working tools used in libraries would reduce the stress brought upon respondents by the inadequacies of available library facilities. The satisfaction derived from the above could go a long way to reduce family squabbles and improve productivity in the office as the events in the home and workplace could be interdependent and mutuallyreinforcing. The establishment of effective welfare scheme, improvement in general working condition, and provision of affordable medical services are vital to the reduction of the various adverse effects of stress. While the benefits of regular exercise and relaxation to healthy living are inestimable, encouragement and appreciation by colleagues, bosses and family members can minimize the stresses brought upon workers through library work and nonwork activities.

\section{Conclusion and Recommendation}

Stress is a common phenomenon and it has no physical form. Thus, library staff are not exempted from the adverse impacts of stress that pervades other professions. Such stressors arise from pressures at home, events at workplace, environmental factors and personal lifestyle. The deleterious effects of stress, as revealed in this report, include: reduced productivity, health complications, marital problems, tiredness and insomnia.

The first logical step in any programme to manage stress so that it remains within tolerable limits is acknowledgment of its existence. That is, any intervention programme targeted at stress-curtailment must first determine whether stress exists and the various contributors to this phenomenon. Awareness of stress and its adverse consequences would triggeroff the natural human instinct for survival. This will challenge the affected individual towards adopting measures for stress management and minimization.

Library personnel should develop positive personal lifestyle since some of the stressors are traceable to the absence of it. They should imbibe the habit of seeing their physicians for relevant medical checkups and treatment whenever they notice any dysfunction in their body system. The human body, when unduly stressed, sends warning signals like tiredness, aching muscles, constipation, sweaty palms, irritability, and pains, among others. As professionals, role models and public servants, library staff should avoid negative lifestyles like quarrelsomeness, alcoholism, drug abuse, and profligacy. They should also cultivate the practice of positive thinking, rest/relaxation, regular exercise and, above all, submission to the will of the Creator of heaven and earth. These would help in reducing the adverse effects of stress amongst the affected.

There is need for improvement on the remuneration, welfare packages and working condition of library personnel. This is against the discovery that majority of the respondents experience stresses arising from inability to meet personnel, family, social and professional responsibilities due to meager earnings. An upward renew of the wages and other welfare packages of library workers would have positive multiplier effects including stress reduction, industrial harmony and increased productivity. As a corollary, basic library professional tools should be made available in the right quality and quantity.

Employers of librarians and library officers should provide medical and counseling services, as both social responsibility and a deliberate effort towards reducing the adverse effects of stress at the workplace. Improving channels of communication, creating a positive corporate culture, appreciation and motivation, helping employees with known maritaland-family problems; and determining what employees consider as job stresses are also steps in the right direction. There is also need to avoid work overload at work and non-work activities to enable library personnel have time for sufficient rest and recreation.

\section{References}

Adair, John and Stonier, J. A. F. (1990). Understanding Motivation. Surrey: The Talbot Adair Press.

Agboola, A. T. and Oduwole, A. A. (2000). "Publication Output of Nigerian Academic Librarians: Case Study from Ogun State". Library Herald. 38(3 \& 4): 132 - 141. 
Baker, Timothy L. (July, 1989). "Preventing Drug Abuse at Work". Personnel Administrator; 56 -59 .

Cattano, Raul (March, 1987). "Public Opinion about Alcoholism and its Treatment". Journal of Studies of Alcohol: 153-160.

Cox, T. (1978). Stress. Baltimore: University Park Press.

Frogatt, T. and Stamp, P. (1991). Managing Pressure of Work. London: B. B. C. Books.

Gibson, James L.; Ivancevich, John. $\mathrm{M}$ and Donnell, James H. (1994). Organization: Behaviour, Structure and Process. Boston: Richard Irwin, Inc.

Holt, Robert R. (1982). "Occupational Stress". In: Goldberg, Leo and Breznitz, Shlomo (eds). Handbook of Stress. New York: Free Press.

Jordan, P. and Norah, J. (1995). Staff Management in Library and Information Work. New Jersey: Thoren's Publishers.

Karasek, Robert and Theorell, Tores (1990). Healthy Work, New York: Basic Books.

Kiecolt-Glaser, Janice and Glaser, Ronald (Summer, 1987). "Psycho-Social Moderators of Immune Function". Annals of Behavioural Medicine: 16-20.

Lauerman, Connie (July, 1992). "The Dress of Success: Stress Makes for Even Harder Days at the Office”. Chicago Tribune Magazine: 1218.

Lefkoe, Morty (June, 1992). "Unhealthy Business". Across the Board: 27-31

Maturi, Richard (July 20, 1992). "Stress can be Beaten". Industry Weekly: 23-26.

Moss, Leonard (Dec., 1989). "Partners for a Drugfree Workplace". Across the Board: 22-31.

Nnadozie, Chuma Opara (2007). Foundations of Library Practice, Owerri, Nigeria: Springfield Publishers Ltd.

Numerof, Rita E. (1983). Managing Stress. Rockville, Md: Aspen Publishers.

Northwestern National Life Insurance, (1991). Employee Burnout: America's Newest Epidemic, Minneapolis: North Western National Insurance Company.

Obi, E. (2003). Organizational Management: Theory and Practice: Enugu: James Publishing

Oduwole, A. A. and Ikhizama, B. O. (2007). Research Output of Librarians in Nigerian Agricultural Institutes". Nigerian Libraries, 40: $27-40$.

Okoye, Tessy and Chikwe, Azuoma (June, 2007). "How Stress Can Reduce Lifespan". Daily Sun, p.33.
Selye, Hans (1976). The Stress of Life. New York: McGraw-Hill Publishing Company.

Stonier, J. A. F. (1992). Management. New Jersey: Prentice-Hall Publishers.

Time Digest (2002). Librarian: Emotion and Stress. Available at: http://www.questionpoint.org. Accessed: - 10-4-2008.

Warren, E. and Towl, C. (1995). The Stress Workbook. London: The Industrial Society Publications. 